\title{
Payment for Ecosystem Services in Sustainable Mangrove Forest Management in Bangladesh
}

\author{
Jona Razzaque*
}

\begin{abstract}
Within the context of sustainable development, both developed and developing countries are implementing policies that encourage economic growth, environmental protection and social well-being in resource decisions. According to the 2012 Rio+20 Declaration, market-based instruments that complement regulations may offer an economically efficient push to sustainable growth. Market-based instruments such as payments for ecosystem services (PES) and other market incentives may play a crucial role in enhancing the livelihoods and wider well-being of poor people. However, economic tools such as PES can prove to be valuable in managing natural resource if the decision making and implementation process integrate adequate rights allocation and participatory mechanisms. Against this backdrop, this article examines the forest ecosystem services in the context of the mangrove reserve forest of the Sundarbans in Bangladesh. It is a UNESCO World Heritage site and one of the largest remaining areas of mangroves in the world with an exceptional level of biodiversity. This article argues for a more realistic and equitable approach to PES projects in Bangladesh. In conclusion, it underscores the need for effective participatory tools, third-party monitoring and multi-service PES schemes to improve multiple mangrove ecosystem services in the Sundarbans.
\end{abstract}

Keywords: Payment for Ecosystem Services, Sustainable development, Mangrove Forest, Sundarbans, Bangladesh.

\section{Introduction}

The Stockholm Declaration, adopted at the 1972 United Nations (UN) Conference on the Human Environment, stated that:

\footnotetext{
*Department of Law, Faculty of Business and Law, UWE Bristol (United Kingdom). Email: Jona.Razzaque@uwe.ac.uk
} 
Man's capability to transform his surroundings, if used wisely, can bring all peoples the benefits of development. ... Wrongly or heedlessly applied, the same power can do incalculable harm to human beings and the human environment. ${ }^{1}$

The intention to transform the surroundings was the key to promoting the concept of sustainable development (SD). ${ }^{2}$ The opportunities as well as challenges for the wise use of natural resources provide an essential impetus for both individuals and the community through a balanced approach between development and conservation. ${ }^{3}$ While inherently a dynamic, indefinite and contested concept, outcomes of SD are dependent on the pathways and operations of each country. The UN Conference on Sustainable Development 2012 outcome document The Future We Want (Rio+20 Declaration), ${ }^{4}$ acknowledged the disparities in policy and institutional frameworks, political circumstances, levels of development, and economic and environmental interdependencies in the global community. For the future implementation of SD, the Rio+20 conference launched a process to develop a set of Sustainable Development Goals (SDGs), ${ }^{5}$ which are built upon the Millennium Development Goals (MDGs). Indeed, countries face different challenges and it will not be an easy task for the SDGs to reflect various national realities, capacities and development priorities. ${ }^{6}$ Nevertheless, it is hoped that an integrated approach to SD would assist collaboration across various fields, sectors and scales by drawing connections between social, economic and environmental spheres, facilitating appropriate policy frameworks at the national level, and recognizing the need to engage local communities. ${ }^{7}$

\footnotetext{
${ }^{1}$ Declaration on the Human Environment, Report of the United Nations Conference on the Human Environment held in Stockholm (Sweden), 5-16 June 1972, UN Doc. A/CONF.48/14/Rev.1 vol. I (1973), para. 3.

${ }^{2}$ Sustainable development is defined in the Brundtland Report as development that 'meets the needs of the present, without compromising the ability of future generations to meet their own needs': World Commission of the Environment and Development, Our Common Future (Oxford University Press, 1987), p. 8; P. Birnie et al., International Law and the Environment (Oxford University Press, 2009), p. 116; P. Sands \& J. Peel, Principles of International Environmental Law, $3^{\text {rd }}$ edn (Cambridge University Press, 2012), p. 215.

${ }^{3}$ Rio Declaration on Environment and Development, adopted by the UN Conference on Environment and Development, Rio de Janeiro (Brazil), 3-14 June 1992, A/CONF.151/26 (Vol. 1), 14 Jun. 1992, available at: http://www.un.org/documents/ga/conf151/aconf15126-1.htm; Johannesburg Declaration on Sustainable Development, Johannesburg (South Africa), 4 Sept. 2002, UN Doc. A/CONF.199/20, Resolution 1, Annex. ${ }^{4}$ UN GA Resolution A/RES/66/288, Resolution Adopted by the General Assembly: The Future We Want, 27 Jul. 2012, para. 246 ('The Future We Want'). Principles that promote SD include justice, dignity, social inclusion, good governance and accountability, resilience, and inter and intra generational equity: ibid., paras. 15-8.

${ }^{5}$ UNGA Resolution, 'Transforming our World: The 2030 Agenda for Sustainable Development'. UN Doc. A/RES/70/1, 21 Oct. 2015. Also see UNGA, Report of the Open Working Group of the General Assembly on Sustainable Development Goals, 12 Aug. 2014, UN Doc. A/68/970.

${ }^{6}$ Organization for Economic Cooperation and Development (OECD), Towards Green Growth (OECD, 2011), p. 10.

${ }^{7}$ J. Robinson, 'Squaring the Circle? Some Thoughts on the Idea of Sustainable Development' (2004) 48

Ecological Economics, pp. 369-84.
} 
The Rio+20 Declaration highlights that while SD remains the highest priority of the international and national development agenda, moving towards a green economy is expected to enable economic growth while increasing environmental quality and social inclusiveness. ${ }^{8}$ Preference is given to market-based instruments such as taxes, permits or payment schemes (e.g., forest certification, payment for forest ecosystem services). Payment for ecosystem services (PES) is gaining recognition worldwide as a promising approach to achieve sustainable development as PES schemes offer economic incentives to individuals and communities for conservation of ecosystem services. ${ }^{9}$ However, many argue that the green economy as well as market-based instruments will advance corporate interests as they promote markets and businesses as a solution to environmental and economic problems. ${ }^{10}$ Failure to ensure that environmental imperatives are factored into economic incentives can result in long-term constraints on future economic opportunities and will have a detrimental effect on social concerns such as poverty alleviation, and food and energy security. ${ }^{11}$

Critics aside, the importance of the ecosystem approach and the relevance of ecosystem services $^{12}$ in forest management are acknowledged in the Rio+20 Declaration. Forests are an example of an ecosystem that attracts internal claims as well as external actors with respect to its management, and highlights the competing parties that need forests for survival. They have a public good dimension because they produce transnational externalities as a result of their exploitation. They are an important source of wood for fuel and food and shelter for local communities - yet, they also serve as carbon sinks and biodiversity reserves for the world at large. Their management is subject to competing claims from environmentalists, the timber industry, and local communities that depend on forest products for their survival. SDG

\footnotetext{
${ }^{8}$ N. 4 above, para. 12 .

${ }^{9}$ For examples of PES schemes, Forest Trends \& The Kattomba Group, Payments for Ecosystem Services Getting Started: A Primer (UNEP, 2008), available at: http://www.unep.org/pdf/PaymentsForEcosystemServices_en.pdf

${ }^{10}$ Friends of the Earth International (FOE), 'Reclaim the UN from Corporate Capture', available at: http://www.foei.org.

${ }^{11}$ W.M. Adams, The Future of Sustainability: Re-thinking Environment and Development in the Twenty First Century (International Union for Conservation of Nature, 2006), pp. 12-3.

${ }^{12}$ Ecosystem services are the benefits people obtain from ecosystems. These include provisioning services such as food, water, timber, and fiber; regulating services that affect climate, floods, disease, wastes, and water quality; cultural services that provide recreational, aesthetic, and spiritual benefits; and supporting services such as soil formation, photosynthesis, and nutrient cycling: Millennium Ecosystem Assessment, Ecosystems and Human Well-Being: Synthesis (2005) p. v, available at: http://www.millenniumassessment.org/documents/document.356.aspx.pdf.
} 
15 emphasizes the social, economic and environmental benefits of forests to people ${ }^{13}$ and affirms 'that the wide range of products and services that forests provide creates opportunities to address many of the most pressing sustainable development challenges' and that there is a need to integrate 'sustainable forest management objectives and practices into the mainstream of economic policy and decision-making'. ${ }^{14}$ It noted:

... the importance of ongoing initiatives such as reducing emissions from deforestation and forest degradation in developing countries; and the role of conservation, sustainable management of forests and enhancement of forest carbon stocks in developing countries. ${ }^{15}$

The challenge is to find a balance between socio-economic development and ecosystem services. This article assesses the sustainability of payments for ecosystem services (PES) in managing the Sundarbans ${ }^{16}$ mangrove forest in Bangladesh. Globally, mangrove forests are one of the most threatened ecosystems and they are shrinking by $0.7 \%$ every year. ${ }^{17}$ The Sundarbans is the largest single tract mangrove forest in the world with a total area of 6017 square kilometres $\left(\mathrm{km}^{2}\right)$, in which $61 \%$ is covered by land and $39 \%$ by water. ${ }^{18}$ The mangroves of the Sundarbans, spanning between India and Bangladesh, are recognized as an internationally important site under the Convention on Wetlands of International Importance especially as Waterfowl Habitat (Ramsar Convention). ${ }^{19}$ It is one of the United Nations Educational, Scientific and Cultural Organization (UNESCO) World Heritage sites as it 'supports an exceptional level of biodiversity in both the terrestrial and marine environments, including significant populations of globally endangered cat species, such as the Royal Bengal Tiger'. ${ }^{20}$ A large amount of forest resources including fuel wood, palm leaves for roofs of local houses, reeds for making local mats, wood for paper, matchbox and hardboard is collected annually from the Sundarbans. It is also the largest national source of honey. More than 300,000 people directly, and more than one million people indirectly, depend on

\footnotetext{
${ }^{13}$ The Future We Want, n. 4 above, paras. 193-6.

${ }^{14}$ Ibid., paras. 193 and 196.

${ }^{15}$ Ibid.

${ }^{16}$ The name Sundarbans literally means 'beautiful forests'. It is also thought that the forest is named after Sundari trees which are found in this mangrove forest. WWF Global, Sundarbans Mangrove: About the Area, available at: http://wwf.panda.org/about_our_earth/ecoregions/sundarbans_mangroves.cfm.

${ }^{17}$ Ecosystem Services for Poverty Alleviation, Tackling the Gaps in 'Market Environmentalism' for Mangroves (2015), available at: http://www.espa.ac.uk/news-events/espa-news/2015-06/64245.

${ }^{18}$ It is a rich area of biodiversity with 334 plant species, 39 species of animal, 53 species of mammal, 330 species of birds, 120 species of fishes and 8 species of amphibians: UNESCO, The Sundarbans. Available at: http://whc.unesco.org/en/list/798 .

${ }^{19}$ Ramsar (Iran), 2 Feb. 1971, in force 21 Dec. 1975, 996 UNTS 245, available at: http://www.ramsar.org/sundarbans-reserved-forest.

${ }^{20}$ World Heritage Convention sites (2016), available at: http://whc.unesco.org/en/list/798.
} 
the Sundarbans for their life and livelihoods. For them, the Sundarbans is a source of life and a safeguard from natural disasters. Along with providing fishing for the livelihoods of people, the Sundarbans provides essential ecosystem services. They protect the coastline from erosion, buffer communities and habitats against storms, produce timber, and work as a carbon sink to combat climate change. ${ }^{21}$ This mangrove forest is a reserve forest and plays a significant role in supporting a wide range of ecosystem services that sustain the livelihoods of local poor communities. In spite of a ban on logging and forest encroachment, there are growing concerns that illegal activities combined with storms and increased salinity are degrading the mangrove ecosystems. ${ }^{22}$

It is thus vital that beneficiaries of mangrove services are integrally involved in mangrove management and restoration planning. In Bangladesh, market instruments such as the PES in forest management have been striving to integrate these competing local and global actors, claims, and concerns. PES schemes have the potential to provide benefits to local poor communities and governments, as well as financial incentives for better manage natural resources. These schemes can offer incentives to mangrove management and encourage sustainable development in sensitive mangrove areas. Payments can be made to mangrove managers for carbon sequestration, storm and flood protection, and aquaculture support. However, market instruments can provide a useful tool in the management of forest resources and in the provisions of ecosystem services only if they are integrated within institutional development and rights allocation.

This article therefore explores the role of PES in relation to forest resources (section 2). It examines the allocation of forest rights (section 3) and participatory rights available to forest communities (section 4). The former argues that while states hold natural assets on behalf of their people for the benefit of present and future generations, these rights have to be effectively allocated among forest users. The latter requires the availability of necessary legal and institutional frameworks to protect victims from procedural weaknesses. Section 5 explores the application of PES in Reduced Emissions from Deforestation and forests Degradation (REDD) schemes. This article argues for a more realistic and equitable approach

\footnotetext{
${ }^{21}$ Md. M. Rahman, Md. N. I. Khan, A. K. F. Hoque \& I. Ahmed, 'Carbon stock in the Sundarbans mangrove forest: spatial variations in vegetation types and salinity zones’ (2015) 23 Wetlands Ecological Management, pp. 269-83.

${ }^{22}$ World Heritage Outlook, Sundarbans National Park Site Description (2015), available at: http://www.worldheritageoutlook.iucn.org
} 
to PES projects. As a market-based instrument, PES requires appropriate national laws, regulations and policies along with adequate economic settings and incentives (e.g., income generating opportunities such as sustainable prawn cultivation, marketing of mangrove products, ecotourism). However, it is feared that additional regulatory and compliance costs may hinder effective implementation of PES projects in the mangrove forest management and undermine the objective to balance competing interests. Section 6 (Prospects for Future Development) underscores the need for prior informed consent, third party monitoring and multi-service PES schemes to improve the multiple mangrove ecosystem services of the Sundarbans.

\section{Payment for Ecosystem Services in the Context of Forest Management}

PES, originally meant as voluntary cash transfers, include all financial and non-financial rewards or compensation mechanisms between the service provider and the service receiver for the provision of an environmental service. ${ }^{23}$ An important indicator of the growing ecological scarcity worldwide was provided by the Millennium Ecosystem Assessment in 2005, which found that over $60 \%$ of the world's major ecosystem goods and services covered in the assessment were degraded or used unsustainably. ${ }^{24}$ A concrete way to move towards sustainable development is to guarantee the good functioning and delivery to society of all types of ecosystem services. However, PES considers that the actions of nature (e.g., forest, water or carbon cycles) are commodities and they are subject to the law of the market. Indeed, pricing of forest ecosystem services presents serious dangers as it may exclude poor people and not always reflect the damage caused to the environment. In addition, valuation of ecosystem services is particularly difficult, especially valuation that takes into account the social costs of introducing market-based mechanisms for services that were previously free. ${ }^{25}$ Therefore, for PES to work effectively within the forest regime, several elements need to be integrated into national laws and policies.

Firstly, the valuation of forest ecosystem services can include direct use value (drinking water, fish and hydropower) or indirect (river flows, flood control and water purification) use

\footnotetext{
${ }^{23}$ FAO Committee on Forestry, Payment for Ecosystem Services for Forests (PES) and Forest Financing, $22^{\text {nd }}$ Session 23-7 Jun. 2014, COFO/2014/4.5, available at: http://www.fao.org/3/a-mk166e.pdf.

${ }_{24}^{24}$ Millennium Ecosystem Assessment, Ecosystems and Human Well-being: Synthesis (Island Press, 2005).

${ }^{25}$ E. Blanco \& J. Razzaque, 'Ecosystem Services and Human Well-being in a Globalized World: Assessing the Role of Law’ (2009) 31 Human Rights Quarterly, pp. 692-720.
} 
value. ${ }^{26}$ For instance, to build a case for investment in mangrove ecosystem management, there is a need to assess the value of various ecosystem services, identify the major stakeholders, and undertake analysis of the socio-economic characteristics and interests of stakeholders, to help ensure that payment schemes are appropriate to their needs. There must be planning of sustainable financing, establishment of an enabling legal and institutional framework, and processes for building public awareness. ${ }^{27}$ In this context, the concern is that this valuation will create a greater divide between the developed and developing countries as PES promotes trade in pollution credits, monoculture and speculative markets (e.g., forests, water, biodiversity). In some cases, the apparent disrespect towards land rights and intergenerational equity (i.e., protecting resources for future generations) makes PES unappealing to those aiming environmental protection and social justice ${ }^{28}$ Although UN agencies and international financial institutions (e.g., the World Bank) offer full support for the valuation of natural capital for land-based communities and indigenous people, some label the process as a commodification of natural resources ${ }^{29}$ and the enclosure of natural areas (e.g., forest, watersheds, wetlands). ${ }^{30}$

Secondly, there are concerns about how the payments will be made. Whatever payment scheme is available (e.g., private, public, permits, certification), the regulation and enforcement mechanisms, standards (e.g., certification standards), and effective monitoring of financial services have to exist to support any payment scheme. ${ }^{31}$ For instance, for mangrove ecosystem services, government agencies, people dependent upon forest resources (fish, timber, honey), small and medium size enterprises and non-governmental organizations (NGOs) need to be involved. Possible service providers include people collecting timber or honey, people involved in aquaculture, and local communities holding communal or common property rights. Third parties or intermediaries in the development of markets for mangrove ecosystem services may include NGOs or financial institutions.

\footnotetext{
${ }^{26}$ UN, The Value of Forests: Payments for Ecosystem Services in a Green Economy, Geneva Timber And Forest Study Paper 34, Geneva (Switzerland), 2014, UN Doc. ECE/TIM/SP/34, available at: https://www.unece.org/fileadmin/DAM/timber/publications/SP-34Xsmall.pdf. 
Thirdly, it is important to ensure that property, access and use rights are well established. This relates to land tenure as well as rights for resource abstraction and use. ${ }^{32}$ The public sector can create incentives (e.g., performance incentives, tax exemptions) and disincentives (e.g., taxes, permits). There may also be grants and donations from individuals for development projects to support conservation, climate adaptation and poverty alleviation. Investment by the private sector for specific forest ecosystem services (e.g., carbon credits, water, biodiversity) may be available. It is also necessary to have legal rights for communities that manage the forest and other related critical ecosystems. These can cover access and use rights, control rights and transfer rights (public, private, communal or openly accessible). Property rights and user's rights vary significantly from country to country and communal management of forests occurs in many developing countries, including Bangladesh. ${ }^{33}$ If the state decides to retain property rights, the government will control all potential benefits. In this case, communities (or other stakeholders) will not have additional motivation to protect forests unless their benefits are secured and guaranteed by a clear legal mandate. Without security and certainty of landholding (through title rights, as well as other rights, interests and remedies), it is difficult to achieve the levels of permanence required to demonstrate ecosystem service benefits.

Fourthly, PES is not a silver bullet and clearly will not work if governance is weak and unable to set favourable enabling conditions, transaction costs are very high, competing destructive resource usages are highly lucrative, or tenure or land use rights are insufficiently defined or enforced, as may be the case for some mangroves, coral reefs, flood plains and forests without clear ownership. ${ }^{34}$ However, under these circumstances, it is unlikely that governments will have alternative regulatory, procedural and remedial tools to effectively manage ecosystem services, as command-and-control regulations are also likely to fail. Many of the PES initiatives (e.g., carbon offsetting via reforestation) allow companies and governments to continue polluting the environment (e.g., through monoculture for biofuel, or plantation of invasive species) in exchange for the ecosystem service provided by forests and agricultural soils in developing countries, which act as carbon sinks. For instance, a large

\footnotetext{
${ }^{32}$ Ibid.

${ }^{33}$ D. Gilmour, Forty Years of Community-based Forestry: A Review of its Extent and Effectiveness (FAO, 2016), available at: http://www.fao.org/3/a-i5415e.pdf.

${ }^{34}$ United Nations, n. 26 above, pp. 27-36.
} 
number of the payment for watershed services ${ }^{35}$ are located in North America and China and funded by the private sector. ${ }^{36}$ PES such as carbon offsetting needs to focus on forest communities and PES approaches need to complement existing conservation tools. Regulatory and governance tools (e.g., land use rights for local and indigenous communities, transparency in the payment scheme, third party audits, adequate funding, access to information, prior informed consent, participation of local/indigenous communities in decision making) need to be strengthened to allow forest stewardship to flourish.

\section{Ecosystem Services and Forest Rights Allocation in Bangladesh}

The state of the Sundarbans mangrove reserve forest is difficult to assess as there are multiple drivers of changes in ecosystem services ranging from climate change and new agricultural methods to specific infrastructural developments (e.g., the Farakka barrage), and local policydriven actions (e.g., commercial shrimp farming). According to a recent study, ${ }^{37}$ the management of ecosystems in the coastal zones of Bangladesh needs to capture the complex dynamics of social-ecological systems (e.g., sea level rise, new land uses, modified river flows, urbanization, new conservation measures). It highlighted that, in Bangladesh, while food and inland fish production is on the rise:

[the] non-food ecosystem services such as water availability, water quality and land stability have deteriorated. Although the shrimp industry is contributing to GDP, this is almost certainly a factor in increasing soil and surface water salinity in this region. ${ }^{38}$

Hossain et al. add that:

[T] he calculations of the economic value of mangrove ecosystem services show that in the long run, the costs to the communities that rely on the mangroves, and society in general who benefit from mangroves carbon storing ability, often exceed the immediate economic gains. Yet despite their efforts the destruction continues as these values fail to make their way into the calculations that inform coastal development decision-making. This means that many existing policies still focus on short term gains which lead to mangrove destruction, such as providing tax breaks for shrimp aquaculture. ${ }^{39}$

\footnotetext{
${ }^{35}$ Payments for watershed functions seek to link upstream land use and management with downstream water use and management to realize benefits for upstream and downstream participants in the scheme, and others in the area, including benefits to the environment.

${ }^{36}$ Natural Capital Markets, Natural Capital Markets for Watershed Services: Actors, Mechanisms, and Impacts, WEBINAR, 16 Apr. 2014, available at: http://www.naturalcapitalmarkets.org/uploads/media/Summary_Webinar_16.04.2014.pdf.

${ }^{37}$ S. Hossain, J. A. Dearing, M. M. Rahman \& M. Salehin, 'Recent Changes in Ecosystem Services and Human Well-being in the Bangladesh Coastal Zone' (2016) 16(2) Regional Environmental Change, pp. 429-43.

${ }^{38}$ Ibid.

${ }^{39}$ Ibid.
} 
As biodiversity becomes rarer and increasingly precious, protected areas - the ecosystems, species, genetic diversity and associated values that societies agree to conserve - are becoming an ever more important focus of interest and concern. ${ }^{40}$ The importance of protected areas is emphasized by international conventions, such as the Convention on Biological Diversity (CBD), ${ }^{41}$ the UNESCO Convention concerning the Protection of the World Cultural and Natural Heritage (World Heritage Convention), ${ }^{42}$ and the Ramsar Convention. ${ }^{43}$ Bangladesh has ratified these multilateral environmental agreements (MEAs). ${ }^{44}$ The significance of these areas is also confirmed by international programmes, for instance, the UNESCO Man and the Biosphere Programme. ${ }^{45}$ The Sundarbans Reserve Forest is a protected area under the Bangladesh Wildlife Preservation Order (1973) with three wildlife sanctuaries managed by the World Heritage Convention since 1997 through the Forest Department (under the Ministry of Environment and Forests). Several values ${ }^{46}$ are attached to such protected area, such as the Sundarbans, ranging from supporting genetic and species diversity ${ }^{47}$ to providing - directly and indirectly - water, food, clothes, shelter, and medicines to human beings. By conserving habitats, protected areas can increase the ecosystems' resilience to climate change and reduce vulnerability of communities to natural disasters, and provide them with livelihood resources to withstand and recover from crises. ${ }^{48}$ At the same time, the economic value (e.g., water, fisheries, timber) of such protected areas or reserve forests cannot be ignored as these areas can offer opportunities for ecotourism and provide jobs and livelihoods. ${ }^{49}$

\footnotetext{
${ }^{40}$ G. Borrini-Feyerabend, N. Dudley, T. Jaeger, B. Lassen, N.P. Broome, A. Phillips, \& T. Sandwith, Governance of Protected Areas: From Understanding to Action, Best Practice Protected Area Guidelines Series No. 20. Gland (Switzerland) (IUCN, 2013), available at: https://cmsdata.iucn.org/downloads/iucn_governance_1109_1.pdf.

${ }^{41}$ Rio de Janeiro (Brazil), 5 June 1992, in force 29 Dec. 1993, available at: http://www.cbd.int.

${ }^{42}$ Paris (France), 16 Nov. 1972, in force 17 Dec. 1975, available at: http://whc.unesco.org/archive/conventionen.pdf or http://whc.unesco.org/en/conventiontext.

${ }^{43}$ N. 19 above.

${ }^{44}$ Department of Environment, Multilateral Environmental Agreements in force in Bangladesh (2016), available at: http://www.doe-bd.org/agreement.html.

${ }^{45}$ Man and Biosphere Programme (2016), available at: http://www.unesco.org/new/en/naturalsciences/environment/ecological-sciences/man-and-biosphere-programme/.

${ }^{46}$ M. Lockwood, A. Kothari \& G. Worboys (eds) Managing Protected Areas: A Global Guide (Earthscan, 2006).

${ }^{47}$ Secretariat of the CBD, Protected Areas in Today's World: Their Values and Benefits for the Welfare of the Planet, Technical Series No. 36 (2008), at p. 1, available at: https://www.cbd.int/doc/publications/cbd-ts-36en.pdf.

${ }^{48}$ K. J. Mulongoy \& S. B. Gidda, The Value of Nature: Economic, Cultural and Social Benefits of Protected Areas (Secretariat of the Conservation on Biological Diversity, 2008), available at: https://www.cbd.int/doc/publications/cbd-value-nature-en.pdf.

${ }^{49}$ IUCN, Sustainable Tourism in Protected Areas: Guidelines for Planning and Management (IUCN, 2002), p. 25; A. Gillespie, Conservation, Biodiversity and International Law (Edward Elgar, 2011), p. 119.
} 
PES has the potential for better forest ecosystem management but presents dangers and social costs unless carefully implemented and monitored inside an equitable and participatory system inclusive of different types of actors. Thus, a clear set of rights is useful for assigning responsibilities, duties, and obligations distributing benefits among different actors (e.g., forest users, government agencies) involved is crucial. Effective forest rights allocation would benefit communities, reduce social conflicts, and promote environmental protection and awareness. ${ }^{50}$ Initiating PES schemes without first protecting and allocating land ownership as well as access and use rights of forest-dependent communities will almost certainly lead to rent-seeking behaviour regarding forests.

The majority of the poor live in rural areas in Bangladesh and depend on forest-related biological resources for survival. ${ }^{51}$ Actions to increase income generation from biodiversity can provide incentives for conservation but can also lead to degradation without the appropriate enabling environment, which involves establishing appropriate rights to resources, access to information and stakeholder involvement. ${ }^{52}$ Parts of the Sundarbans were declared a Wildlife Sanctuary in the 1970s to conserve animals and trees. A moratorium on felling of the dominant Sundari tree was enacted in 1989 and a $20 \mathrm{~km}$ buffer area around the forest was declared an 'Ecologically Critical Area' in 2006. Finally, after the devastation caused by Hurricane Aila in 2007, a ban on all timber extraction was put in place. The three wildlife sanctuaries of the Sundarbans are managed by the Forest Department which allocates permits for nypa palm (golpata), honey and fish. ${ }^{53}$ However, illegal logging is high in the Sundarbans and the forest department, with little manpower, is unable to control or monitor illegal activities. The level of corruption is also high, which is cited as the main reason for the massive destruction of timber and non-timber related forest products. ${ }^{54}$

\footnotetext{
${ }^{50}$ FAO, State of the World's Forests: Forests And Agriculture: Land-Use Challenges and Opportunities (2016), chapter 3, available at: http://www.fao.org/3/a-i5588e.pdf. See also Gilmour, n. 33 above.

${ }^{51}$ M.M. Rahman, 'Forest resources of Bangladesh with reference to conservation of biodiversity and wildlife in particular for poverty alleviation' in H.C. Sim, S. Appanah \& Y.C. Youn (eds.) Forests for Poverty Reduction: Opportunities with Clean Development Mechanism, Environmental Services and Biodiversity (FAO, 2003) pp. 139-48, available at: http://www.fao.org/3/a-ae537e.pdf

${ }^{52}$ Millennium Ecosystem Assessment, Ecosystems and Human Well-being: Biodiversity Synthesis (World Resources Institute, 2005), p.12, available at: http://www.maweb.org/documents/document.354.aspx.pdf.

${ }^{53}$ Ministry of Environment and Forest, Type of Forests and Management (in Bengali), available at: http://www.moef.gov.bd/.

${ }^{54}$ M. E. Khoda, Transparency and Accountability in Forest Conservation and Management: Problems and Way Out(Transparency International Bangladesh, 2008), available at: http://www.ti-bangladesh.org/beta3/images/max_file/rp_es_forest_08.pdf.
} 
Prior to the Sundarbans being declared as a reserve forest in 1977, a number of forestry conservation plans were adopted that prioritized the need for wildlife conservation as well as revenue collection from timber. ${ }^{55}$ The first National Forest Policy, in 1979, inadequately addressed issues such as sustainability, community participation and their livelihoods. ${ }^{56}$ The government claims sole ownership of the Reserve Forest and has the ultimate authority to manage the forest resource collection. ${ }^{57}$ There are no recognized local rights within the reserve forest, and the population surrounding the Sundarbans has not yet been able to participate in the strategies and activities aimed at conserving the forest and using its resources sustainably. The Constitution of Bangladesh is not much help either as it does not provide any explicit protection of forests and wildlife. The Supreme Court of Bangladesh has stated that the constitutional "right to life' ${ }^{58}$ does include a right to a safe and healthy environment, thus offering an implied protection of forestry resources.

Articles 31 and 32 of our Constitution protect right to life as a fundamental right. It encompasses within its ambit, the protection and preservation of environment, ecological balance free from pollution of air and water, sanitation without which life can hardly be enjoyed. Any act or omission contrary thereto will be violate of the said right to life. ${ }^{59}$

The forest-related laws of Bangladesh adopt a command and control approach, demonstrate a lack of coherent policies and institutions, and encourage socially and ecologically conflicting centralized management regimes. According to the Forest Act 1927 of Bangladesh: ${ }^{60}$

28A. (1) On any land which is the property of the Government or over which the Government has proprietary rights, and on any other land assigned to the Government by voluntary written agreement of the owner for the purpose of afforestation, conservation or management through social forestry, the Government may establish a social forestry programme ...

The Social Forestry Rules 2004 (Amendment 2010) recognizes this provision of the Forest Act and ensures local community participation in afforestation activities in Government-

\footnotetext{
${ }^{55}$ For example, the Forest Policy of 1894 and the Forest Policy of 1947-71 prioritized economic interests that led to resource destruction.

${ }^{56}$ N. Muhammed, M.Koike \& F. Haque, 'Forest policy and sustainable forest management in Bangladesh: an analysis from national and international perspectives.' (2008) 36 (2) New Forests, 201-16.

${ }^{57}$ Forest Department, Project Concept Note: Collaborative REDD+IFM Sundarbans Project (CRISP) (Forest Department, 2011); S. Karim, 'Proposed REDD+ Project for the Sundarbans: Legal and Institutional Issues' (2013) 1 International Journal of Rural Law and Policy, pp. 1-7.

${ }^{58}$ Article 31 and 32 together incorporate the fundamental 'right to life'. Article 31 states that every citizen has the right to protection from 'action detrimental to the life liberty, body, reputation, or property'. Article 32 states: 'No person shall be deprived of life or personal liberty save in accordance with law'. If these rights are taken away, compensation must be paid.

${ }^{59}$ M. Farooque v. Bangladesh (1996) 48 Dhaka Law Reports, 438.

${ }^{60}$ The Forest Act 1927, Act No. XVI of 1927, available at: http://bdlaws.minlaw.gov.bd/print_sections_all.php?id=144.
} 
owned forest land. ${ }^{61}$ The Rules are formulated to ensure participation of local communities in planning and management of social forestry programmes. The National Biodiversity Strategy Action Plan for Bangladesh 2004 described co-management as 'the sharing of authority, responsibility and benefits between government and local communities in the management of natural resources'. ${ }^{62}$

Policies supporting co-management approaches to natural resource management include the Bangladesh Forestry Department's Nishorgo Vision 2010, which focuses on co-management and community partnerships as strategies for strengthening the management of protected areas. $^{63}$ This network, supported by the United States Agency for International Development USAID, calls for enhanced protected area management, including co-management, and urges the adoption of participatory mechanisms to promote biodiversity management, use, and benefit sharing with local communities and other partners. Other projects that focus on the Sundarbans include the United Nations Development Programme's UNDP Community-based Adaptation to Climate Change through Coastal Forestation project that aims to promote coastal areas works with tree plantations, fisheries and livestock rearing by expanding livelihood options for climate-vulnerable communities. ${ }^{64}$ Another example is the USAID funded Integrated Protected Area Co-management project (IPAC), ${ }^{65}$ managed by the Forest Department, which seeks to engage local stakeholders through a participatory comanagement process, empowering them with decision-making rights and positive incentives, thus promoting their interest in, and commitment to, the protection of biodiversity resources. ${ }^{66}$ IPAC developed Project Design Documents for forestry voluntary carbon market projects that include Collaborative REDD+ Improved forest management Sundarbans Project

\footnotetext{
${ }^{61}$ The Social Forestry Rules 2004 (in Bengali), available at: http://fd.portal.gov.bd/sites/default/files/files/fd.portal.gov.bd/page/0c05d1d9_54b2_4b0c_91d3_b1008b50c591 /Social\%20Forestry\%20Rules\%202004.pdf. The Social Forestry Rules (amended in 2010) is available at: http://moef.portal.gov.bd/

62 National Biodiversity Strategy and Action Plan for Bangladesh (2004), available at: http://www.indiaenvironmentportal.org.in/files/file/NBSAP\%20bangladesh.pdf.

${ }^{63}$ USAID, Welcome to Nishorgo Network, available at: http://www.nishorgo.org/.

${ }^{64}$ Bangladesh REDD+ Readiness Roadmap; CBACC-CF is supported by the Strategic Priority to Adaptation Fund of the Global Environment Facility.

${ }^{65}$ IPAC, 2008-2013. USAID, IPAC Project: IPAC Implementation and Management Strategy, available at: http://www.nishorgo.org/?id=40

${ }^{66}$ Bangladesh REDD+ Readiness Roadmap UN-REDD Programme, Draft 1.2, Apr. 2012. This IPAC project included 28 protected forest areas (e.g., national parks and wildlife sanctuaries) and aimed at enhancing carbon stocks and reducing GHG emissions through restoration, conservation and sustainable management of forests. See also: http://pdf.usaid.gov/pdf_docs/Pdacm045.pdf.
} 
(CRISP), ${ }^{67}$ discussed in section 5 below. So far, social forestry has had limited success in Bangladesh. $^{68}$

For the effective implementation of the projects, clear guidance is needed on land use and ownership. While social forestry is crucial to mangrove forest management, the central management of forestry fails to stop encroachment and settlement of forest land. In the case of the Sundarbans, forest ownership lies with the government, but there is an extreme shortage of trained forest officials. ${ }^{69}$ The command-and-control approach in forest law does not encourage community participation and benefit sharing, nor does it promote alternative livelihoods for communities living at the edge of the forest to curb their dependency on the Sundarbans. ${ }^{70}$ For instance, according to some critics, the Asian Development Bank (ADB) funded Sundarbans Biodiversity Conservation Project $(\mathrm{SBCP})^{71}$ operated on the basis of a 'design framework [that] failed to recognize the profound interdependence among the forest, its wildlife and its human inhabitants - the traditional resource users'. ${ }^{72}$

This project was fundamentally flawed, as its primary effect was to destroy this interdependence by creating artificial, alien and short-term resource and livelihood systems for the local communities and indigenous people in the name of 'poverty reduction', and distance them from their ecosystem. ${ }^{73}$

A recent incident in the Sundarbans highlights the ineffective nature of Bangladesh forest law and legal remedies. In December 2014, an oil tanker accident in the Sundarbans of Bangladesh led to the release of approximately 358,000 litres of heavy fuel oil into the river

\footnotetext{
${ }^{67}$ The other two projects under IPAC are: Chunati Wildlife Sanctuary Management of Natural Resources and Community Forestry Project, and Bangladesh REDD+ Afforestation, Reforestation and Revegetation in Protected Areas Project.

${ }^{68}$ Nishorgo, Management Plan for Teknaf Game Reserve (2006), available at: http://www.nishorgo.org/tbltd/upload/pdf/0.00839000\%201354826954_4.5_Management\%20plans\%20for\%20 Teknaf\%20Game\%20Reserve.pdf. The Nishorgo Program of the Forest Department was created in 2004 through support from USAID and the International Resource Group to promote a co-management model for administering the protected areas of Bangladesh including the Sundarbans by focusing on building partnerships between the Forestry Department and key local, regional and national stakeholders.

${ }^{69}$ Khoda, n. 54 above.

${ }^{70}$ S. G. Sen, Conservation of Sundarbans in Bangladesh through Sustainable Shrimp Aquaculture (2010), available at: http://www.innovations.harvard.edu/sites/default/files/1227364.pdf.

${ }^{71}$ Asian Development Bank, Bangladesh: Sundarbans Biodiversity Conservation Project, Validation Report, (2008), available at: https://www.adb.org/sites/default/files/evaluation-document/35664/files/in285-08.pdf.

72 J. Hossain \& K. Roy, Deserting Sundarbans: Local People's Perspectives on ADB-GEF-Netherlands funder Sundarbans Biodiversity Conservation Project (2007), available at:

http://unnayan.org/reports/Deserting.the.Sundarbans.pdf.

${ }^{73}$ Ibid, at p. 7.
} 
and mangrove ecosystem. ${ }^{74}$ The response to the incident by the government Ministry was excruciatingly slow. At the request of the Ministry of Environment and Forests of Bangladesh, a Joint UN/Government of Bangladesh Sundarbans Oil Spill Response mission was formed under the coordination of the UNDP. ${ }^{75}$ The objective of the mission was to strengthen the Government's efforts in containing and cleaning up the oil spillage, as well as to provide support for assessing the situation and developing an action plan for a phased response and recovery. The lack of a formal oil spill contingency plan, weak response management and response infrastructure, along with a lack of effective monitoring, impeded response and recovery efforts. As of March 2015, only 68,200 litres of oil had been recovered $^{76}$ - the rest continues to pollute the forest ecosystems (e.g., water, fisheries, wildlife) and affect human health and livelihoods. While some people benefitted economically from the oil recovery scheme, the UNEP/OCHA report emphasised the health and environmental risk and referred to the incident as a 'serious wake up call' for Bangladesh. ${ }^{77}$ Shipping oil through the forest poses a serious threat to the forest and forestdependent communities, and there are insufficient appropriate safeguards and mitigation measures in place. Within two months of imposing a ban on the shipping route, the government lifted the ban on cargo boats, although oil tankers remain banned. ${ }^{78}$

\section{Stewardship and Participatory Democracy}

The government, as the land owner and steward, has a duty to the community to protect and preserve the mangrove forest. ${ }^{79}$ In this sense, the government is the trustee to conserve the forest land for the benefit of present and future generations. The government owes a duty to the people to provide access to information and enable them to participate in decision-making processes in relation to the mangrove forest. At the same time, NGOs and local communities are also involved in forest stewardship - i.e., managing and conserving the forest and related

\footnotetext{
${ }^{74}$ Sundarbans Oil Spill Assessment, Joint United Nations/Government of Bangladesh Mission, Dec. 2014, available at: whc.unesco.org/document/140155.

${ }^{75}$ Ibid. The mission consisted of 25 experts and officials from Bangladesh Government agencies and universities, the United Nations Disaster Assessment and Coordination (UNDAC) team, UNDP, USAID, the European Union Civil Protection Mechanism, France and the Wildlife Conservation Society.

${ }^{76}$ Oil Stained Wastes Finally being Removed from Sundarbans, 25 Mar. 2015, available at: http://en.ntvbd.com/bangladesh/2479/Oil-stained-wastes-finally-being-removed-from-Sundarban/print. ${ }^{77}$ N.74 above.

${ }^{78}$ Author unknown, Bangladesh Lifts Ban on Cargo Boats After Sundarbans Oil Spill, 7 January 2015 , available at: http://www.ndtv.com/world-news/bangladesh-lifts-ban-on-cargo-boats-after-sundarbans-oil-spill723933.

${ }^{79}$ E. Barritt, 'Conceptualising Stewardship in Environmental Law' (2014) 28(2) Journal of Environmental Law, pp. 9-14.
} 
resources. However, the hierarchical approach to mangrove forest management in Bangladesh, as exemplified in its reliance on command and control regulation, limits a more participatory mode of governance. Participatory democracy requires the availability of necessary frameworks to protect victims from procedural inequity and increased participation involving a set of actors (e.g., government authorities, users, local community, NGOs, industries). ${ }^{80}$ The participatory process needs to be fair, inclusive and open, and it is thought that public participation improves the outcomes of the process by enhancing their legitimacy. ${ }^{81}$ Public participation is an area which could potentially enhance public trust in government decision making, and thus reduce litigation. ${ }^{82}$ Public involvement in decision making and environmental information could help to achieve a better decision in the first place, and mitigate the need to resolve disputes in court in the long run. By integrating the people's voice in the decision-making process, supplying community groups with environmental information and opening access to the environmental assessment reports, the government not only can achieve high quality natural resource management, it can also contribute to reducing social and economic inequalities. ${ }^{83}$

On the one hand, the forest laws in Bangladesh mention the problems of over consumption (for fuelwood or timber) and the unsustainable exploitation of resources (e.g., due to poverty, illegal logging, land grabbing). ${ }^{84}$ On the other hand, participatory approaches are weakly incorporated into forest-related regulations (e.g., lack of free prior informed consent of the forest community). The Forest Policy 1994 and the Social Forestry Rules (2004) incorporate participatory forestry and allow cooperation between state and non-state actors. The Poverty Reduction Strategy Paper $2013^{85}$ and the Bangladesh Climate Change Strategy and Action Plan $2008^{86}$ both explicitly emphasize the importance of participatory forest resource

\footnotetext{
${ }^{80}$ D. Vitale, 'Between Deliberative and Participatory Democracy: A Contribution on Habermas' (2006) 32(6) Philosophy Social Criticism, pp. 739-66, at p. 752.

${ }^{81}$ B. Richardson \& J. Razzaque, 'Public Participation in Environmental Decision-making' in B. J. Richardson \& S. Wood (eds.), Environmental Law for Sustainability (Hart, 2006), pp. 165-94.

${ }^{82}$ W.M. Tabb, 'Environmental Impact Assessment in the European Community: Shaping International Norms' (1999) 73 Tulane Law Review, pp. 923-60, at p. 953.

${ }^{83}$ J. Razzaque, 'Participatory Rights in Natural Resource Management: Role of Communities in South Asia' in J. Ebbesson \& P. Okowa (eds.), Environmental Law and Justice in Context (Cambridge University Press, 2009), pp. 117-38.

${ }^{84}$ J. K. Choudhury \& Md. A. A. Hossain, Bangladesh Forestry Outlook Study (FAO, 2011), available at: http://www.fao.org/3/a-am628e.pdf

${ }^{85}$ International Monetary Fund, Bangladesh Poverty Reduction Strategy Paper (March 2013) pp. 197-9. IMF Country Report No. 13/63, p. 202. https://www.imf.org/external/pubs/ft/scr/2013/cr1363.pdf.

${ }^{86}$ Government of the People's Republic of Bangladesh, Bangladesh Climate Change Strategy and Action Plan 2008, available at:http://www.sdnbd.org/moef.pdf .
} 
management. However, the forest regime of Bangladesh is centrally controlled by the Forest Department with little or no genuine involvement of the local people. ${ }^{87}$ Forest management is more focused on generating revenues from timber production and sidelines the contributions of the non-wood forest products to local livelihoods and forest sustainability. ${ }^{88}$

The social forestry rules in the National Forest Policy 1994 promote benefit-sharing arrangements to alleviate poverty. The Policy states in para 1, 'the Government shall work jointly with NGOs and ensure people's participation'. It further states: 'Denuded and encroached Government forest lands will be identified and brought under afforestation program with people's participation on benefit sharing approach... ${ }^{89}$ While social forestry related projects have led to better quality of life of the participants, ${ }^{90}$ some of these projects are dogged with criticisms regarding a lack of local stakeholder consultation in planning and management of forest resources along with donor-driven agendas, weak local level institutions and a top-down policy approach. ${ }^{91}$

Some sectoral laws in Bangladesh require the participation of people in decision making and include provisions on environmental impact assessment (EIA). ${ }^{92}$ However, participation is limited to the project initiation level. Consultation is often pro forma and does not promote an effective decision-making process. A study ${ }^{93}$ of the EIA of a proposed coal-based thermal power plant highlights the problems associated with consultation processes in Bangladesh. The proposed power plant is to be situated 14 kilometres downstream from the Sundarbans in Rampal upazila of Bagerhat beside the Poshur river and will generate 1320 megawatts (MW) of electricity. In 2012, the Bangladesh government signed a joint venture agreement with India's state-run electricity generation company, National Thermal Power Corporation

\footnotetext{
${ }^{87}$ A. K. Dev Roy \& K. Alam, 'Participatory Forest management for the Sustainable Management of the Sundarbans Mangrove Forest' (2012) 8(5) American Journal of Environmental Science, pp. 549-55, available at: https://eprints.usq.edu.au/6279/2/Roy_Alam_AJES_2012_PV.pdf . million tonnes of coal annually when more or less 0.3 million tonnes ashes and around 0.5 million tonnes sludge and liquid waste may be produced. Available at:

http://www.banktrack.org/download/annex_2_eia_dr_abdullah_harun_et_et_pdf/annex2_eia_dr_abdullah_harun _et_et.pdf .
} 
Limited, under the name of Bangladesh -India Friendship Power Company Limited. ${ }^{94}$ According to the agreement, the NTPC is responsible for planning, building and operating the plant. ${ }^{95}$ Although the Department of Environment (Bangladesh) approved the project, it has imposed 59 conditions ${ }^{96}$ and the no-objection certificate is yet to be granted. ${ }^{97}$. According to the critics of the project, the high level of carbon dioxide $\left(\mathrm{CO}_{2}\right)$ emitted from the power plant, and the contamination of groundwater by the huge volume of waste produced due to the burning of the coal (e.g., arsenic, mercury, cadmium, chromium) will destroy the mangrove forest and its ecosystem services. ${ }^{98}$ Another study of the EIA process of this coal-based power plant ${ }^{99}$ found that the process lacked adequate engagement and consultation with stakeholders. According to the report, most consultees did not have a clear idea about the extent of the project, the project location or project risks. There was a lack of transparency around issues of compensation, resettlement and rehabilitation. Moreover, no grievance mechanism was established to address and resolve the concerns of people harmed by the acquisition of land. A 2015 report by Transparency International Bangladesh ${ }^{100}$ highlights that powerful political party leaders and administration officials threatened to file cases and take legal actions against those who opposed the power plant. More recently, three French

\footnotetext{
${ }^{94}$ Bangladesh Power Development Board, Final report on Environmental Impact Assessment of 2x[500-660) MW Coal Based Thermal Power Plant to be Constructed at the Location of Khulna, Government of the People's Republic of Bangladesh (January 2013), available at: http://www.bpdb.gov.bd/download/coal_EIA_report_rampal_khulna/EIA\%20of\%202x\%20(500660)\%20MW\%20Coal\%20Based\%20Thermal\%20Power\%20Plant\%20at\%20Rampal\%20in\%20Bagerhat $\% 20 \mathrm{D}$ istrict, $\% 20$ Khulna.pdf.

${ }^{95}$ More than $70 \%$ shares of the NTPC Limited are owned by the Government of India.

${ }^{96}$ Department of Environment, Approval of Environmental Impact Assessment (EIA) Report for Proposed Khulna 1320 MW Coal Based Thermal Power Plant Construction Project at Rampal Upazila under Bagerhat district, Memo No : DoE/Clearance/50622011/206, Date 08/08/2013, available at: http://bifpcl.com/new/wpcontent/uploads/2014/06/Approval-of-EIA.pdf .

${ }_{97}$ Author unknown, Rampal power plant project yet to get environmental clearance: minister, Star Online Report, 9 June 2016. Available at: http://www.thedailystar.net/city/rampal-power-plant-project-yet-getenvironmental-clearance-minister-1236952

${ }^{98}$ Chowdhury, n. 93 above. South Asian for Human Rights, Report of the Fact Finding Mission to Rampal, Bangladesh (2015), available at: http://www.southasianrights.org/wp-content/uploads/2015/09/Report-of-theFFM-Rampa-Bangladesh.pdf .

${ }^{99}$ BankTrack, Equator Principles Analysis of the Rampal coal-fired power plant project, Bangladesh (June 2015). Available at:

http://www.banktrack.org/manage/ems_files/download/rampal_equator_principles_full_analysis_pdf/rampal_eq uator_principles_full_analysis.pdf .

${ }^{100}$ Transparency International Bangladesh, Rampal and Matarbari Power Projects: Governance Challenges in Environmental Impact Assessment and Land Acquisition (April 2015). TIB recorded evidence of financial irregularities, unethical transactions, and widespread corruption. Available at: http://www.tibangladesh.org/beta3/images/2015/es_ffs_coal_15_en.pdf.
} 
Banks and two Norwegian Pension Funds refused to invest in the Rampal project citing environmental and social concerns. ${ }^{101}$ Public protests against the project are ongoing. ${ }^{102}$

At the forest project implementation level, people's concerns were rejected on several occasions. The ADB funded SBCP ignored the local people's perspective. ${ }^{103}$ This US $\$ 77.3$ million project aimed to establish a proper management system to protect the biological diversity and secure the environmental and biological integrity of the Sundarbans. The project was undertaken with the objective to improve the declining biodiversity conditions of the Sundarbans through poverty reduction, participatory management and development. ${ }^{104}$ The project was intended to take place between 1999 and 2006, but the ADB suspended the project in 2003 citing problems with project design, the implementation of some activities, and financial management. In 2005, the ADB formally and unilaterally cancelled its commitment, blaming Bangladesh's Forest Department for failing to take steps to revise the project. This project also failed to adequately consult with local communities, did not adhere to the ADB and the Global Environment Facility (GEF) guidelines on consultation and transparency (e.g. local people had restricted access to project document), did not address how the proposed 'participatory forest management' and 'peoples' involvement' would be achieved within a national institutional and legal framework, did not incorporate the local communities' and indigenous peoples' traditional knowledge, and did not provide any grievance mechanisms to victims. ${ }^{105}$ Corruption of the monitoring agency, i.e., the Forest Department of Bangladesh, was another reason for the ADB to terminate the project. According to critics, 'the SBCP prevented local people from entering the jungle for their livelihoods, and allowed outside encroachers to smuggle forest resources more freely'. ${ }^{106}$

In sum, while the hierarchical approach may be effective in the event of an urgent or imminent threat (e.g., oil spill, forest fire), a participatory approach is superior when policy makers aim to attain multiple, and sometimes conflicting, sectoral goals. In addition, deliberative participatory processes will be more effective when implementation is dependent

\footnotetext{
${ }^{101}$ J. Lenin, 'French Banks says no to Bangladesh Coal Plant', The Guardian, 25 June 2015. Available at: http://www.theguardian.com/environment/blog/2015/jun/25/french-banks-say-no-to-bangladesh-coal-plant ${ }_{102}$ Online Desk, 'Long march planned against Rampal project', Prothom Alo, 14 May 2016. http://en.prothom-alo.com/bangladesh/news/104637/Long-march-planned-against-Rampal-project . ${ }_{103}$ Hossain \& Roy, n. 72 above.

${ }^{104}$ ADB, n.71 above.

105 Hossain \& Roy, n.72 above.

${ }^{106}$ ibid. p. 8.
} 
on the cooperation of local actors. In Bangladesh, the law does not provide any guidance as to the determination of what constitutes a significant impact in particular situations or on the role of public participation. Participation and information requirements are limited. On many occasions, the government agencies simply sideline impact assessment requirements. More importantly, for political reasons, it is not always possible to access courts to challenge a resource decision of the government. Unfortunately, there is no provision for quasi-judicial mechanisms to resolve conflicts in these circumstances.

\section{REDD+, PES and the Forest: The North Proposes, the South Adapts}

REDD+ is defined as:

reducing emissions from deforestation and forest degradation in developing countries; and the role of conservation, sustainable management of forests and enhancement of forest carbon stocks in developing countries. ${ }^{107}$

REDD+ activities may include PES. ${ }^{108}$ REDD+ payments made to forest users for reforestation to incentivize conservation or to tackle the drivers of deforestation and forest degradation are examples of PES transactions. ${ }^{109}$ Government-financed PES programmes for forest management can be found in China, Costa Rica, and Mexico. ${ }^{110}$ The funding for REDD+ activities may come from national and international, public and private sources. ${ }^{111}$ PES schemes may play a larger role in REDD+ activities if they contribute to the livelihood and well-being of local communities. However, a lack of clear policies, experience, and confidence in PES hinders its adoption in many developing countries. ${ }^{112}$

\footnotetext{
${ }^{107}$ UNFCCC decision 1/CP.13. Bali Action Plan, 13th session of the Conference of the Parties (COP) to the UNFCCC in 2007.

${ }^{108}$ P. A. Lopes, 'Is REDD Accounting Myopic?: Why Reducing Emissions from Deforestation and Forest Degradation Programs Should Recognize and Include Other Ecosystems and Services Beyond CO 2 Sequestration', (2011) 11(2) Sustainable Development Law and Policy, pp. 25-32. K. Wilkinson, 'Payment for 'ecosystem services' and the 'green economy': green-washing or something new?' (2014) 5 (2) Journal of Human Rights and the Environment, 168-91.

${ }^{109}$ World Bank, Lessons Learned for REDD+ from PES and Conservation Incentive Programs: Examples From Costa Rica, Mexico, and Ecuador (2012), available at: http://www.forestcarbonpartnership.org/sites/forestcarbonpartnership.org/files/Documents/Full\%20version\%200 f\%20PES\%20Lessons\%20for\%20REDD+\%20March\%202012.pdf ${ }^{110}$ Ibid.

${ }^{111}$ UN-REDD Programme Strategic Framework 2016-20 (Revised Draft - 7 May 2015) UN Doc. UNREDD/PB14/2015/III/3, available at: http://www.un-redd.org/work-programme.

112 World Bank (2012), n. 109 above.
} 
Within forest governance, REDD+ offers a 'political and economic trade off' opportunity between developed and developing countries. ${ }^{113}$ Both the Stern Review and the 2007 Intergovernmental Panel on Climate Change IPCC Report demonstrated that deforestation contributes approximately $18 \%$ of anthropogenic $\mathrm{CO}_{2}$ emissions. ${ }^{114}$ These estimates supported the decisions at the Conference of the Parties (COP) 13 and $15^{115}$ of the United Nations Framework Convention on Climate Change (UNFCCC) ${ }^{116}$ to adopt measures for REDD+. ${ }^{117}$ "As an initiative "to" the South, "from" the North', both developed and developing countries actively participated during REDD negotiations to make it part of the solution to climate change whereby developed countries can offset their emissions and promote sustainable development in developing countries. ${ }^{118}$ While a large number of developing countries have readiness policies to reduce forest-based emissions, problems remain with REDD-related governance mechanisms which need to be transparent and inclusive.

Can PES schemes help to implement REDD+ activities in Bangladesh? REDD is a developing theme in Bangladesh. ${ }^{119}$ After joining the UN-REDD Programme in 2010, the Government of Bangladesh established a national REDD+ Steering Committee and a REDD Cell. During 2011-12, the UN-REDD Programme supported these national bodies in the development of a National REDD+ Readiness Roadmap, including extensive national and sub-national consultations. The REDD+ Steering Committee of Bangladesh endorsed the Roadmap in December 2012. ${ }^{120}$ With Targeted Support funds, UN-REDD now supports the implementation of some elements of the Roadmap, namely, the development of a monitoring, reporting and verification (MRV) Action Plan, capacity building for forest monitoring, an assessment of REDD+ corruption risks, and development of nationally-appropriate social

\footnotetext{
${ }^{113}$ T. Cadman \& T. Maraseni, 'The governance of REDD+: an institutional analysis in the Asia Pacific region and beyond' (2011) 55(5) Journal of Environmental Planning and Management, pp. 617-35.

${ }^{114}$ N. Stern, Stern Review: The Economic of Climate Change (Her Majesty's Treasury, 2006), p. xxv. IPCC, Climate Change 2007: Synthesis report, An Assessment of the Intergovernmental Panel on Climate Change. Valencia, Spain, 12-17 November 2007, p. 5.

${ }^{115}$ Decision 2/CP.13 (2007), FCCC/CP/2007/6/Add.1 and Decision 4/CP. 15 (2009), FCCC/CP/2009/11/Add.1.

${ }^{116}$ New York, NY (US), 9 May 1992, in force 21 Mar. 1994, available at: http://unfccc.int.

${ }^{117}$ In September 2008, the UN-REDD Programme was launched.

${ }^{118}$ Cadman \& Maraseni, n. 113 above.

119 For example of proposed REDD in Chittagong (Bangladesh), see: http://www.rufford.org/rsg/projects/md_danesh_miah (accessed on 10 August 2016).

${ }^{120}$ UNDP, UN-REDD Bangladesh National Programme, available at: http://mptf.undp.org/factsheet/project/00090410
} 
safeguards. ${ }^{121}$ Currently, UNDP and the Food and Agriculture Organisation of the United Nations FAO are assisting the Government of Bangladesh to implement targeted support activities funded by the UN-REDD Programme on corruption risk assessment, social impact assessment and MRV. ${ }^{122}$ Projects such as the REDD+ARR Protected Area Project promotes carbon stock enhancement through Afforestation, Reforestation and Revegetation (ARR). ${ }^{123}$ Another example is the project called 'Collaborative REDD+ Improved Forest Management Sundarbans Project' (CRISP) developed by the Forest Department of Bangladesh. ${ }^{124}$ The main objectives of the project are to achieve carbon sequestration as well as livelihoods improvements through community participation in forestry activities, and the conservation of flora and fauna species through measures including habitat protection and improvement. The emissions reductions will be achieved by reducing deforestation and forest degradation. Here, REDD+ payments constitute a payment for ecosystem services by offsetting opportunity costs. These projects can play an important role in facilitating participation by the poor and marginalized in PES schemes.

It is interesting to note that REDD+ schemes in Bangladesh are not only about climate financing mechanisms - they also aim to be foster sustainable forest management ${ }^{125}$ and halt the trends of deforestation and degradation as they are equally critical to protecting the livelihoods of millions of the country's extreme poor. ${ }^{126}$ In a country like Bangladesh, any performance-based payments would require supportive legal and policy frameworks, as well as effective MVR. In addition, the REDD+ programme must promote wide participation of local communities and provide adequate protection to other ecosystems and services beyond carbon sequestration. Some fear that the mangrove forest is being monetized into carbon credits. The 'Sundarbans Forest Carbon Inventory-2009' conducted by the Forest Department

\footnotetext{
${ }^{121}$ REDD Readiness Preparation Proposal (April 2014), available at: http://www.unredd.org/Newsletter37/Bangladesh_Climate_Financing_Sector/tabid/106148/Default.aspx

${ }^{122}$ Information on other parallel projects supporting REDD+ readiness can be found in the REDD Readiness Preparation Proposal (April 2014).

${ }^{123}$ United States Agency for International Development under Contract No. EPP -1-00-06-00007-00 (Jan 2012). Available at: http://pdf.usaid.gov/pdf_docs/PA00JFT7.pdf.

${ }^{124}$ Collaborative REDD+IFM Sundarbans Project (CRISP), Project Concept Note (February 2011), available at: http://www.nishorgo.org/tbltd/upload/pdf/0.84199100\%201357815512_CRISP.pdf .

${ }^{125}$ According to Food and Agricultural organisation, Sustainable forest management addresses forest degradation and deforestation while increasing direct benefits to people and the environment. http://www.fao.org/forestry/sfm/en/.

${ }_{126}$ UN-REDD, UN Collaborative Programme on Reducing Emissions From Deforestation and Forest Degradation in Developing Countries, National Programme Document, (May 2015) available at: http://www.unredd.net/index.php?view=download\&alias=14573-bangladesh-npdsigned\&category_slug=national-programme-documents-2040\&option=com_docman\&Itemid=134. UNDP, Bangladesh government officially launched the UN-REDD Bangladesh National Programme (3 August 2016).
} 
of Bangladesh with assistance from USAID and other international donors already determined the economic value of the mangroves. ${ }^{127}$ This economic valuation was criticized by local NGO platform as this approach promotes commodification of forests and has the potential to sideline the interests of indigenous and local forest communities. ${ }^{128}$ The REDD+ projects need to adopt a balanced approach and maximize synergies between poverty reduction, adaptation to climate change, and conservation of forest resources.

To promote social and environmental benefits and reduce risks from REDD+, the UN-REDD programme has drafted Social and Environmental Principles and Criteria, which include several principles and criteria of relevance to biodiversity protection. ${ }^{129}$ Biodiversity safeguards developed outside the UNFCCC context ${ }^{130}$ seek to ensure that REDD+ does not adversely affect biodiversity. However, it remains uncertain how various international standards will be enforced at the national level. ${ }^{131}$

In addition, the World Bank's Forest Carbon Partnership Facility plays an important role in financing REDD+ activities and requires participating countries to carry out a Strategic Environmental and Social Assessment. These assessments may, in turn, help prevent the negative impacts of REDD+ implementation. ${ }^{132}$ The Bank's own operational policies include further safeguards of relevance for biodiversity protection, such as World Bank operational policies 4.01 on environmental assessment and 4.36 on forests. ${ }^{133}$ Using these assessments could help identify and reduce adverse impacts at the planning stage. However, the problems associated with EIAs in Bangladesh (for example, the Rampal Thermal Power Plant project, discussed in section 4) highlight that the EIA process is often weak and the outcome can be

\footnotetext{
${ }^{127}$ USAID, Integrated Resources management Plans for the Sundarbans (2010-2020), available at: http://pdf.usaid.gov/pdf docs/pnaec417.pdf. .

${ }^{128}$ Campaign for Climate Justice. Carbon Trading and the Sundarbans: United States Interest conflicts with local people's rights. Campaign Paper: March 2011. Equity and Justice Working Group-Bangladesh and Humanitywatch.

${ }^{129}$ UN-REDD Programme Social and Environmental Principles and Criteria (2012). UN-REDD Programme Eighth Policy Board Meeting, UN Doc. UNREDD/PB8/2012/V/1.

${ }^{130}$ For example, REDD+ Social and Environmental Standards (SES), developed by two nongovernmental organisations, Climate, Community, and Biodiversity Alliance (CCBA) and CARE International.

${ }^{131}$ C. McDermott, L. Coad, A. Helfgott and H. Schroeder, 'Operationalizing Social Safeguards in REDD+: Actors, Interests and Ideas' (2012) 21 Environmental Science and Policy, pp. 63-72.

${ }^{132}$ The Forest Carbon Partnership Facility was created to assist developing countries to reduce emissions from deforestation and forest degradation, enhance and conserve forest carbon stocks, and sustainably manage forests (REDD+). Available at: http://www.climatefundsupdate.org/listing/forest-carbon-partnership-facility .

${ }^{133}$ C. McDermott et al, 'Governance for REDD+, Forest Management and Biodiversity: Existing Approaches and Future Options' in J.A. Parotta, C. Wildburger \& S. Mansourian (eds), Understanding Relationships between Biodiversity, Carbon, Forests and People: The Key to Achieving REDD+ Objectives (IUFRO, 2013), pp. 115-37.
} 
ignored by the decision makers. Moreover, Bangladesh already faces problems of high levels of corruption - examples can be found in relation to the Climate Change fund ${ }^{134}$ and the ADB funded Sundarbans Biodiversity Conservation project. ${ }^{135}$ The fear also remains that the Forest Department with its centrally controlled power will introduce a new framework for forest bureaucracy over the Sundarbans which will allow the Department to manipulate forestrelated data and access funds. Indeed, monitoring and reporting of the biodiversity impacts of REDD+ activities would help clarify how REDD+ can best contribute to biodiversity conservation goals. However, monitoring in practice will require improved coordination between national-level actors responsible for REDD+ implementation and biodiversity protection. While safeguards provide an important means of ensuring that REDD+ does not undermine biodiversity objectives, 'the pursuit of biodiversity goals may involve tradeoffs with other goals ascribed to REDD+, including maximising emission reductions and costeffectiveness'. 136

\section{Prospects for Future Development}

The extent to which a sovereign country provides an opportunity to protect forest resources depends upon the values the country attributes to these resources in the face of external economic pressure, and the effectiveness of law and remedies.. It is clear that for a country like Bangladesh to preserve short-term economic gains, the long-term public benefit is often overlooked. Decision making in relation to sustainable forest management is driven by financial concerns and commercial interests, and rights to access fundamental public goods from nature are jeopardized by short-term economic interests. There is very little understanding why certain ecosystem services need to be prioritized over others and ecosystem-related concerns are not integrated within decision-making processes. Local communities are not efficiently involved in the decision-making process across the full range of ecosystem services. There is no independent monitoring or audit available, and the government agencies fail to play an effective oversight role to ensure actions that conform to agreed standards.

\footnotetext{
${ }^{134}$ M. Z.H. Khan, Bangladesh: Cutting off our head to cure a headache? (3 July 2014), available at: http://blog.transparency.org/2014/07/03/bangladesh-cutting-off-our-heads-to-cure-a-headache/; Transparency International, 2011-2015: Making sure climate money gets to where it's needed, available at: http://www.transparency.org/whatwedo/activity/making sure climate money gets to where its needed . ${ }^{135}$ S. Karim, n. 57 above. . ADB, n. 71 above.

${ }^{136}$ H. V. Asselt, 'REDD+ and Biodiversity' in E. Morgera \& J. Razzaque (eds.) Biodiversity and Nature Protection Law (2017, Edward Elgar, in press)
} 
PES schemes in Bangladesh can manage and deliver ecosystem services at the local level if the focus is on rewarding and encouraging positive behaviour, and making the polluter pay for poor environmental practices. Yet, any monetary valuation will have to be transparent about the underlying assumptions and weaknesses, and realistic in its claims and ambitions. At the same time, any payment needs to capture the long-term commitment to environmental ends. There are several ways in which this payment can be made: small financial contributions by the government (e.g., payment under the social forestry programme), local business directly or indirectly gaining financially from the improved ecosystem services, or visitors contributing to PES schemes (e.g., eco-tourism). However, the risk remains that the 'payment' will be lost due to corruption. It is also not clear what the 'payment' will be used for. Faced with a multitude of commitments under international agreements and pressure from UN agencies and Northern donor agencies and financial institutions, Bangladesh seems increasingly ill-prepared to capitalize on the benefits from PES schemes.

In Bangladesh, multi-stakeholder partnerships ${ }^{137}$ show some positive results. For instance, the Mangroves for the Future ${ }^{138}$ and Ecosystem for life ${ }^{139}$ projects are creating a platform for long-term partnerships for biodiversity management at the national and trasnboundary (IndiaBangladesh) level involving civil society, government, and the private sector. The Sundarbans Environmental and Livelihoods Security (SEALS) programme 2010-14, funded by the European Commission, aims to 'contribute towards the maintenance and improvement of 'ecosystem productivity' of the Sundarbans Reserve Forest (SRF) and induce 'environmental and social integrity' in the habitats around the Sundarbans. ${ }^{140}$ One crucial aim of this programme is to develop alternative livelihoods for SRF dependent communities. Another aim is to equip the Forest Department to protect and manage the Sundarbans. While it is too early to assess the impact on local communities, this project is showing some success. For instance, the Sundarbans Development and Alternative Resources Integration

\footnotetext{
${ }^{137}$ Mangroves for the Future, Ecosystems across Borders: MFF at the World Parks Congress 2014, available at: http://www.mangrovesforthefuture.org/news-and-media/news/asia-region/2014/mff/.

${ }^{138}$ Mangroves for the Future, Bangladesh, available at:

https://www.mangrovesforthefuture.org/countries/members/bangladesh/.

${ }^{139}$ IUCN, Ecosystem for Life: A Bangladesh-India Initiative (2013), available at:

http://bangladesh.nlembassy.org/binaries/content/assets/postenweb/b/bangladesh/netherlands-embassy-indhaka/import/water-management/project-documents/e41/e4l-annual-report-2012.pdf.

${ }^{140}$ EuropeAid, Annual Work Programme for Grants of the Delegation of the European Union to Bangladesh Sundarbans Environmental And Livelihoods Security (SEALS) project (2011), available at: https://ec.europa.eu/europeaid/sites/devco/files/awp-bangladesh-forest-seals-2011_en.pdf; Bangladesh Economic News, Tk 128cr project to develop ecosystems in Sundarbans, 15 January 2011, available at: https://bangladesheconomy.wordpress.com/2011/01/15/tk-128cr-project-to-develop-ecosystems-in-sundarbans/
} 
(SUNDARI) project 2012-2015 - funded by the SEALS Programme - works closely with the extreme poor households of the Sundarbans and offers training on non-timber SRF products. ${ }^{141}$ The German government-funded Sustainable Development and Biodiversity Conservation in coastal protection forests ${ }^{142}$ collaborates with a private shrimp-processing company on the greening of dikes. The company works with 3,500 small-scale farmers to produce certified organic shrimps that are sold in Germany and France. Communities are given training on the sustainable cultivation of the nypa palm as well as alternative livelihood strategies, such as honey collection.

The challenges in Bangladesh are many. Firstly, multi-service PES schemes that value and seek to improve multiple ecosystem services within the mangrove forest have the potential to foster a synergy between the delivery of different ecosystem services. Such multi-service schemes may offer opportunities to combine multiple sources of funding from a range of beneficiaries. Partnership and co-management initiatives based on a modified form of social forestry may work in Bangladesh. However, such partnerships will need to be self-sustaining strategic partnerships involving a broad range of local organizations, businesses and local communities with the credibility to influence other local strategic decision makers. The challenge here is to capture the multiple values (e.g., eco-tourism, water quality, soil erosion) of the mangrove forest.

Secondly, top-down forestry regulations may not, on their own, be the best option to protect forest ecosystem services because of a lack of effective legal remedies, cost implications, and uncertainty surrounding liability. Formal regulations can cause delay, cost, uncertainty in prosecutions and, in many instances, they may be ineffective as 'individual retribution' or 'general deterrence', ${ }^{143}$ without generating any improvement in standards or performance

\footnotetext{
${ }^{141}$ The SUNDARI Project is officially managed by Concern Worldwide. 31 community based organisations, 18 producers and collectors group and 1845 self help group have been formed with the targeted 25000 Sundarbans Dependent Extreme Poor Households. Concern Worldwide, SUNDARI: Protecting the Biodiversity of the Sundarbans by Reducing Human Pressure, available at: https://www.concern.net/sites/default/files/media/resource/sundari__protecting_the_biodiversity_of_the_sundarbans_by_reducing_human_pressure.pdf .

${ }_{142}$ The project works on behalf of the German Federal Ministry for Economic Cooperation and Development (BMZ) and supports the implementation of the Bangladesh Climate Change Strategy and Action Plan. It is particularly relevant for the disaster management, and capacity building and institutional strengthening pillars of that strategy. GIZ, Sustainable Development and Biodiversity Conservation in Coastal Protection Forests (2010), project number 2010.2220.1, available at: https://www.giz.de/projektdaten/projects.action?request_locale=en_EN\&pn=201022201 .

${ }^{143}$ Law Commission (UK), Criminal Liability in Regulatory Contexts, Consultation Paper No 195 (2010) 3.
} 
levels. As a solution, some suggest the use of permits and licences, environmental assessments and self-regulation. ${ }^{144}$ Market-based approaches such as tax incentives and subsidies can complement 'command and control' mechanisms. However, market-based approaches may be limited in scope and unable to cope with complex forest ecosystemrelated problems. ${ }^{145}$ In contrast, a 'hands-off' approach that encourages voluntarism and selfregulation ${ }^{146}$ (e.g., NGO standards) can cause a legitimacy deficiency.

Thirdly, policy frameworks need to support institutions and facilities. Along with strengthening forest institutions (e.g., the Sundarbans Environmental And Livelihoods Security (SEALS) project), the donor agencies (e.g., USAID, the European Commission) and international financial institutions (e.g., the World Bank, ADB) need to apply their own policies and guidance on, for instance, EIA and community resettlement. However, the way in which some of these foreign financial institutions conduct their activities in Bangladesh has been criticized on the basis of failure to assess risk associated to project ${ }^{147}$ or funding in polluting project. ${ }^{148}$

Fourthly, embracing the uncertain realm of REDD+ without ascertaining its impact on forest ecosystem services is extremely ill-advised. Greater clarity on the future interplay between PES and REDD+ is required. Also, along with adherence to biodiversity safeguards, different schemes and projects must ensure consistency and comparability of how emissions and offsets are measured, verified and reported. The emphasis on creating financial incentives may result in valuation conflicts between actors (state and non-state) engaged in forest issues at all levels. In addition, NGOs are not homogenous; there is a divide between NGOs that

\footnotetext{
${ }^{144}$ E. Skinnider, Victims of Environmental Crimes - Mapping the Issues (International Centre for Criminal Law Reform and Criminal Justice Policy, 2011) 20.

${ }^{145}$ N. Gunningham, 'Environment Law, Regulation and Governance: Shifting Architectures' (2009) 21(2) Journal of Environmental Law, pp. 179-212, at p. 186.

${ }^{146}$ According to Gunningham and Sinclair, "self-regulation entails social control by an industry association, whereas voluntarism is based on the individual firm undertaking to do the right thing unilaterally, without any basis in coercion." N. Gunningham \& D. Sinclair, Designing Smart Regulation (1999), pp. 1-19, at p. 16, available at: http://www.oecd.org/env/outreach/33947759.pdf..

${ }^{147}$ For example, the ADB's role in the Sundarbans Biodiversity Conservation project. Hossain \& Roy, n. 72 above. ADB, n. 71 above.

${ }^{148}$ For example, the role of NTPC Limited and the World Bank in the proposed Rampal Power Plant Project. BankTrack, n. 99 above. Inclusive Development International, "Disaster for Us and the Planet": How the IFC is quietly funding a coal boom. Outsourcing Development: Lifting the Veil on the World Bank Group's Lending Through Financial Intermediaries, Part 1, October 2016, available at: http://www.inclusivedevelopment.net/wp-content/uploads/2016/09/Outsourcing-Development-Climate.pdf
} 
embrace market-based approaches and conservation NGOs. Forest NGOs with greater funding often have greater roles in policy decisions and implementation.

\section{Concluding Comments}

As in the forestry management of many developing countries, market values and short term economic benefits are prioritized in the mangrove forest management in Bangladesh. Reflexive regulation, safeguards and monitoring for REDD+ in many mangrove forest countries are unachievable due to weak governance. This article highlighted the divergence between developed countries' enthusiasm for market-based regulation and safeguards, and developing countries' ability effectively to deliver such strategies. Moreover, the increasing involvement of non-state actors in forest governance, their accountability and the legitimacy can be questioned. In addition, disappointments of the local people due to a lack of effective local engagements with relevant stakeholders underscore the need to have a credible monitoring of social outcomes and impacts. Through enabling policy and institutions, PES can be an effective tool to achieve environmental as well as social benefits in the mangrove forest management. With the growth of REDD+ in Bangladesh, the cooperation among state and non state actors should not only be about prioritising different interests and clarifying legal obligations. Such cooperation should also accommodate community and environmental values of forest ecosystem services, initiate monitoring strategy to assess the impacts of PES projects, and promote effective participatory tools to empower forest dependent communities. 